\title{
Effects of the News-Finds-Me Perception in Communication Social Media Use Implications for News Seeking and Learning About Politics
}

\begin{abstract}
$+$
Abstract

With social media at the forefront of today's media context, citizens may perceive they don't need to actively seek news because they will be exposed to news and remain well-informed through their peers and social networks. We label this the "news-finds-me perception," and test its implications for news seeking and political knowledge: "news-finds-me effects.” U.S. panelsurvey data show that individuals who perceive news will find them are less likely to use traditional news sources and are less knowledgeable about politics over time. Although the newsfinds-me perception is positively associated with news exposure on social media, this behavior doesn't facilitate political learning. These results suggest news continues to enhance political knowledge best when actively sought.
\end{abstract}

Keywords: News-finds-me perception, News-finds-me effect, News use, Political Knowledge, Social Media.

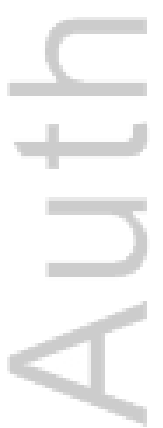

This is the author manuscript accepted for publication and has undergone full peer review but has not been through the copyediting, typesetting, pagination and proofreading process, which may lead to differences between this version and the Version of Record. Please cite this article as doi: $10.1111 /$ jcc4.12185

This article is protected by copyright. All rights reserved. 


\section{Effects of the "News-Finds-Me" Perception in Communication}

\section{Social Media Use Implications for News Seeking and Learning About Politics}

Citizens today arguably have more opportunities to encounter news and political information than ever before. In addition to traditional media outlets such as television, newspapers, and radio, the ubiquity of news on the Internet and within social media offer people the possibility to be exposed to news whether or not they actively seek it out (Hermida, 2010; Gil de Zúñiga \& Hinsley, 2013; Pew, 2016). At first glance, the widespread availability of news might be considered ideal for producing better-informed citizens, especially given that both the volume and breadth of news in the media environment promote learning about politics (Barabas \& Jerit, 2009) and that unintentional news exposure can facilitate political knowledge (Shehata, Hopmann, Nord, \& Höijer, 2015; Tewksbury, Weaver, \& Maddex, 2001).

While the abundance of media options may provide citizens more opportunities to learn from the news, some scholars argue that this high-choice media environment may instead have negative democratic consequences by enhancing political knowledge gaps based on content preferences, interest, and usage patterns. Here, individuals who seek out and take advantage of the plethora of news available may benefit most from political news, while those who do not purposefully seek news will not see gains in political knowledge despite the wealth of information in the media environment (e.g. Hopmann, Wonneberger, Shehata, \& Höijer, 2016; Prior, 2007; Wei \& Hindman, 2011). Thus, one of the central aspects of this debate is whether political learning is dependent on citizens actively seeking news and political information or whether people can passively learn about politics through incidental exposure (Shehata et al., 2015). 
If scholars are interested in whether or not political learning is predicated on active news engagement, it also becomes necessary to better understand how citizens' perceptions of the contemporary media environment relate to news exposure patterns. Within this context, one unexplored possibility is that the glut of news, particularly on the Internet and within social media, may negatively impact whether people actively seek news and ultimately whether they learn from it. Although traditional news outlets such as television news and newspapers continue to remain popular among certain segments of the population, many Americans, especially younger adults, are also increasingly exposed to news via websites, apps, and social networking sites like Facebook and Twitter (Pew, 2016); these social media in particular have changed how people receive news. Social media create a confluence of news by simultaneously providing users news not only from traditional media outlets but also news created and shared by others in the social network. As a result, users within these social networks can be exposed to news directly by actively seeking it, or incidentally, without any explicit effort of their own, through their use of these sites (Kim, Chen, \& Gil de Zúñiga, 2013; Tewksbury et al., 2001).

The availability and abundance of news in people's lives has created what some scholars have labeled "ambient news" (Hargreaves \& Thomas, 2002). Ambient news suggests that news today is ubiquitous, pervasive, and constantly all around us (Hermida, 2010). Hargreaves and Thomas (2002) note that while individuals want to be informed about significant events in the news, the ambient nature of news today may lead some people to believe they do not need to regularly follow the news to stay informed (p. 5). As people increasingly encounter news and political information online, including content shared by others in their social networks, might they come to believe that they no longer need to actively seek news and information to remain politically knowledgeable? If the current media environment is facilitating such perceptions, what 
effect do they have on citizens' news-seeking behaviors and knowledge about politics? While intriguing, these questions have not been addressed in the context of the contemporary media environment, nor have they been rigorously tested empirically.

To address this gap in the literature, this study introduces and tests what we call the newsfinds-me perception and effect. The news-finds-me effect stems from individuals' perceptions that a) they are well informed about current events despite not purposely following the news, because b) the important information "finds them" anyway, through their general media use, peers, and social connections. Here we test the effects of these perceptions on individuals' active news consumption patterns and political knowledge levels. Using demographically diverse, twowave online panel survey data collected in the United States, we find that individuals who perceive that they do not need to actively seek news are significantly less likely to use traditional news channels, including television and print news, but more likely to get news from social media. More importantly, we find negative consequences for holding this misperception, as individuals who believe they are well-informed despite not actively seeking news are, in time, significantly less knowledgeable politically than those who do not hold that perception. Our results suggest that actively seeking news remains important in order for citizens to learn about politics and civic affairs.

\section{News-Finds-Me Perception and the Contemporary News Environment}

We define the news-finds-me perception as the extent to which individuals believe they can indirectly stay informed about public affairs — despite not actively following the news_through general Internet use, information received from peers, and connections within online social networks. Thus, it captures people's perceptions that news will simply "find" them without seeking it. Importantly, the news-finds-me perception does not reflect ambivalence 
toward using news to stay informed - it is not that those who hold this perception are necessarily uninterested in what is happening in the world - but rather believe that they do not need to actively seek news because their other media behaviors and social network provide all the news they require to stay informed. The perception is also distinct from motivations to consume news. For example, one individual may not be motivated to consume news but still feel up to date on current affairs, while a different individual may be highly motivated to follow news and feel that they are informed through their network, even if those motivations to consume news do not translate into actively seeking the news.

Nor does the news-finds-me perception capture simple avoidance of news. News avoidance suggests an active and conscious effort to avoid news content, whereas the newsfinds-me perception fuels a failure to actively seek news. It is not that individuals who feel the news will find them are avoiding news, they just do not feel that they must go and find it. This is a subtle but important distinction. Moreover, most people do not have an active desire to avoid the news altogether (Trilling \& Schoenbach, 2013) and more than 70\% of Americans continue to regularly follow the news (Pew, 2016). Furthermore, the ambient nature of news and its prevalence on social media make it difficult to completely avoid exposure to news (Hargreaves \& Thomas, 2002; Pew, 2016). In fact, individuals who hold these perceptions may continue to be exposed to news through their use of social media. After all, as more individuals incorporate social media into their media diets, the opportunity for inadvertent exposure to news also increases (Pew, 2014). Many social media users, for instance, use these platforms to disseminate and discuss news with others in their social network (Weeks \& Holbert, 2013). Inevitably, other users within these social networks will be exposed to this news content without any explicit 
effort of their own (Kim et al., 2013; Tewksbury et al., 2001). In this way, using social media for news may facilitate news-finds-me perceptions.

While news-finds-me perceptions may be a function of using social media as a source of news, it may also be that holding this belief further encourages news exposure within these sites. For example, individuals who hold the news-finds-me perception may believe that social media fulfills their news needs, which might lead them to more consistently turn to social media as a source of news. That is, if people believe the news will find them without actively seeking it, they will likely need to continue to use and rely on social media as a source of news to maintain the perception of being informed. In this way, use of social media for news and news-finds-me perceptions may have a cyclical relationship. Using social media for news enhances the newsfinds-me perception, which may subsequently encourage further use of social media as a source of news. We therefore expect the following:

H1: Social media use for news will be positively related to news-finds-me perceptions. Perceptions of the media environment can influence the extent to which people use certain media (e.g. Iyengar \& Hahn, 2009) and we expect news-finds-me perceptions to have important implications for individuals' media use behaviors outside of social media. One of the central characteristics of the news-finds-me perception is the belief that one need not actively follow the news because others in an individual's social network will provide relevant and necessary information. This implies a strong reliance on others for news, which is a hallmark of the two-step flow of information. The two-step flow suggests that news can flow from the mass media to the general public through opinion leaders. In this model, certain individuals who are highly interested and involved with news (i.e. opinion leaders) will consume news and subsequently disseminate what they learn to their peers, often in an attempt to persuade them 
(Katz \& Lazarsfeld, 1955). In the contemporary media environment, opinion leaders actively discuss, share, comment on, and produce news and political information (Park, 2013; Weeks, ArdévolAbreu, \& Gil de Zúñiga, 2015), which may contribute to the news-finds-me perception and affect subsequent media use behaviors. The abundance of news online and in social media is overwhelming for some individuals, which may lead them to depend more on other people in their networks and less on traditional media to filter relevant news for them (Pentina \& Tarafdar, 2014). If people consistently see others discussing news or sharing information online, they may be less likely to actively seek news because they are confident that they are informed about political affairs through their social connections and general media use. Tuning into television news, reading a newspaper, or listening to the news on the radio would all simply be superfluous to those with the news-finds-me perception, as this information is not likely to have much additional utility, given that people already feel sufficiently informed (e.g. KnoblochWesterwick, Carpentier, Blumhoff, \& Nickel, 2005). Indeed, individuals who report that friends and family are an important source of news are less likely to actively seek news from news organizations (Pew, 2016).

If individuals who are high in news-finds-me perceptions feel their information needs are met through their peers and social networks, the high-choice contemporary media environment makes it even more unlikely that they will seek additional news from traditional media sources. Given the multitude of options unrelated to news or politics available to media consumers today (entertainment, sports, movies, etc.), some argue individual-level characteristics and motivations have become increasingly important determinants in whether people selectively expose themselves to political news or not (Prior, 2007). Individuals who feel that they will learn from news, are interested in politics, or enjoy news are more likely to actively seek political news than 
those who are not (e.g. Min, 2010) and some evidence indicates the relative influence of these personal characteristics on media choice has increased as the number of media options has grown (e.g. Hopmann et al., 2016; Strömbäck, Djerf-Pierre, \& Shehata, 2013). Based on these theoretical foundations, individuals who believe the news finds them and feel they are informed should therefore be less likely to purposefully expose themselves to news from traditional news outlets.

H2: People's news-finds-me perception in time 1 will be negatively related to traditional media news use (i.e., TV, radio, and print newspaper) in time 2.

\section{News-Finds-Me Effect on Political Knowledge}

The hypothesized impact of news-finds-me perceptions on news consumption raises the related question of whether this perception also affects individuals' knowledge about politics. News media are important sources for citizens to learn about politics (e.g. Barabas \& Jerit, 2009; Delli Carpini \& Keeter, 1996) but there is concern that the high-choice media environment will widen gaps in political knowledge between individuals who actively seek news and those who do not. Prior to the widespread adoption of cable television and the Internet, people were often incidentally exposed to news (typically on television), which allowed individuals who did not actively seek news to remain relatively well-informed compared to their news seeking peers. Given that citizens today have nearly unlimited media options and often select nonnews content, the concern is that actively seeking news is now a requirement in order for people to learn about politics (Hopmann et al., 2016; Prior, 2007). While the expansion of the media environment may have altered incentives to purposefully select news content, the growth of social media has also increased citizens' opportunities to learn about politics through incidental or unintended exposure to news within these platforms (Bode, 2016; Dimitrova, Shehata, Strömbäck, \& Nord, 
2014). Such incidental learning may therefore allow people to be informed despite not seeking the news (e.g. Elenbaas, de Vreese, Schuck, \& Boomgaarden, 2014; Tewksbury et al., 2001).

At the center of the debate about contemporary knowledge gaps is the question of whether political learning can occur in the absence of actively seeking news, or whether political knowledge can be acquired incidentally through use of other media (Shehata, 2013). In other words, must political learning be active or can passive learning about politics from media occur? Active learning is argued to be a function of purposeful selection of media content rather than available media content. Individuals who want to learn more about their political environment and actively seek news pay closer attention to and elaborate more deeply on news content, which facilitates political learning (e.g. Eveland et al., 2003; David, 2009; Prior, 2007). For example, Hopmann et al. (2016) found support for the active learning hypothesis, demonstrating that over time political interest has become an increasing important factor driving news exposure and political knowledge. According to this argument, political learning is therefore primarily a result of personal characteristics such as preferences, motivations, interest, or, in the present study, news-finds-me perceptions (see Shehata, 2013). Given that news-findsme perceptions represent a failure to actively seek news, notions of active learning would suggest that those high in this belief would have lower levels of political knowledge, because they are not actively seeking or processing the news content necessary to learn. That is, if people perceive that the news will find them without explicit effort, they will no longer seek the news content needed to keep them informed and their knowledge should suffer.

However, it is also possible that incidental exposure to news and political information can facilitate knowledge gains through passive learning. Notions of passive learning via media are based on the idea that contextual factors such as the sheer volume of information can encourage 
learning despite existing individual-level factors that could dampen knowledge, such as newsfinds-me perceptions (Shehata, 2013). Learning about politics is therefore not simply a matter of desire to learn but also opportunity and availability of information (Elenbaas et al., 2014). Here, the abundance of news today inevitably means that citizens will be incidentally exposed to political information without actively seeking it through their general media use (Hermida, 2010). Such inadvertent exposure provides numerous opportunities to passively learn through exposure to relevant information (Krugman \& Hartley, 1970; Zukin \& Snyder, 1984). Numerous studies support the passive learning hypothesis, noting that information environments containing high levels of political news and information can enhance political knowledge through mere exposure, even for individuals who do not actively expose themselves to news (e.g. Elenbaas et al., 2014; Iyengar et al., 2010; Kobayashi \& Inamasu, 2015; Shehata, 2013; Shehata et al., 2015; Tewksbury et al., 2001). Extending the findings in support of passive learning to the present study, it is possible that individuals high in news-finds-me perceptions may passively learn about politics despite not actively seeking the news through their use of other media.

Taken together, some research indicates that active engagement with the news is required for political learning, while other work demonstrates that individuals may acquire knowledge passively through their other media use alone. Given that the news-finds-me belief reflects individuals' perceptions of the omnipresence of news and its consequences on political knowledge, this study seeks to shed light on this regard:

RQ1: What is the relationship between individuals' perceptions that the news finds them and their political knowledge?

News-Finds-Me Perceptions, Social Media Use, and Political Knowledge 
Much of the discussion in the literature over media exposure and political learning has focused on the role of television or general Internet use in facilitating or diminishing knowledge gaps based on personal characteristics (e.g. Elenbaas et al., 2014; Hopmann et al., 2016; Iyengar et al., 2010; Kobayashi \& Inamasu, 2015; Prior, 2007; Shehata et al., 2015). Yet, in the contemporary media environment it is social media that may provide a promising opportunity for exposure to news, passive learning about politics, and reduction of potential knowledge gaps between those who believe the news will find them and those who do not (Bode, 2016). Social media allow for exposure to news shared by peers, as well as journalists and media organizations, who have a strong presence on these sites (Weeks \& Holbert, 2013). It is therefore not surprising that social media have become an important source of news for many citizens and that people report frequent incidental exposure to news while using these sites for other purposes (Kim et al., 2013; Pew, 2016). If the concern is that personal characteristics reduce the likelihood that some individuals actively seek and learn from news, social media may attenuate those worries by exposing people to news. Individuals high in news-finds-me perceptions may be less likely to actively seek news from traditional news sources but, as noted above, they should turn to social media for news. Social media may therefore offer the necessary context and opportunity for individuals high in news-finds-me perceptions to passively learn about politics without actively seeking additional news from sources outside of these platforms, potentially reducing any knowledge gap that stems from this perception.

However, there are also reasons to believe that social media will not facilitate political knowledge gains for those high in news-finds-me perceptions. It may be that the content preferences or individual characteristics that can create knowledge gaps via other media use are also present on social media (Prior, 2007). Individuals who feel that the news will find them may 
see news in social media but not click on it, attend to it, or process it in any depth. In such instances, simple exposure may not be enough for passive learning to occur as it can with television (Shehata, 2013). For instance, although people can recall political information from social media (Bode, 2016), according to researchers political knowledge has either exhibited no links with social media use (Dimitrova et al., 2014), or only enhances learning for those high in education (Yoo \& Gil de Zúñiga, 2014). Despite the wealth of news and information in social media, active learning may therefore be required in this platform. Furthermore, there are questions about whether social media provide the type of news necessary for people to learn. Bright (2016) found that relative to a number of other news topics, social media users share news about politics at a much lower level, perhaps to avoid offending others. Over time, this may create what he calls a "social news gap," in which people who consume news on social media hold different perceptions of the news agenda than traditional news users, which may lead social media news users to become disinterested and disengaged with political news altogether (Bright, 2016). If so, social media could exhibit the same preference- and individual-based knowledge disparities outlined by Prior (2007).

As noted above, we expect individuals' perceptions that the news will find them to be positively related to social media use for news. We have also outlined reasons why using social media for news may or may not subsequently facilitate political learning. Given these conflicting theoretical accounts, we ask whether those who feel the news will find them learn about politics indirectly, through their use of social media for news:

RQ2: Do people's news-finds-me perceptions have an indirect effect on political knowledge, through use of social media for news?

\section{Method}




\section{Sample}

This study relied on U.S. survey data collected in two waves by Research Unit at The University of Vienna. The study used web-based survey platform (Qualtrics) to administer the online panel and to deliver the questionnaire to respondents. Subjects' panel is curated by the media-polling group Nielsen, which was contracted to obtain the study's sample. Nielsen selects participants from over 200,000 people previously registered users. In order to secure maximum data quality integrity, representability and generalizability, Nielsen stratifies a quota sample from this panel of registered users, ensuring specified quotas that match the U.S. census for gender, age, education, and income. This procedure has been validated by previous research (e.g. Bode, Vraga, Borah, \& Shah, 2013; Iyengar \& Hahn, 2009).

Wave 1 of the survey was conducted between 15 December 2013 and 5 January 2014. From an initial sample of 5,000 individuals, 1,813 participants provided complete and valid data. Based on the American Association of Public Opinion Research response rate calculator (AAPOR, 2011), the response rate was 34.6\%, which is within the acceptable parameters for online panel surveys (see special volume on online panel data, Bosnjak, Das, \& Lynn, 2015). Wave 2 data were collected from 15 February to 5 March 2014, gathering information from 1,024 cases (retention rate of $57 \%$ ). The retention rate also falls into the acceptable interval to maintain data and representation (see Watson and Wooden, 2006). The sample was slightly older, more educated, and included fewer Hispanics than the U.S. census. Yet, the overall sample is sufficiently similar to the U.S. census and also comparable to other surveys utilizing similar sampling strategies (for complete demographic breakdown see Saldaña et al., 2015)

\section{Dependent Variables}

This article is protected by copyright. All rights reserved. 
Social media use for news. Building on previous studies (Gil de Zúñiga et al., 2012, 2013), we created an index of social media use for news by averaging 11 items measured on a 10-point scale $(1=$ never to $10=$ all the time $)$. Eight items asked respondents how often they used Facebook, Twitter, Google+, Pinterest, Instagram, Tumblr, Reddit, and LinkedIn for getting news. Three more general items captured information regarding how often respondents used social media "to stay informed about current events and public affairs," "to get news about current events from mainstream media," and "to get news from online news sites" (W1 Cronbach $\mathrm{s} \pm=.89, \mathrm{M}=1.94, \mathrm{SD}=1.31 ; \mathrm{W}^{2}$ Cronbach $\left.\mathrm{s} \pm=.89, \mathrm{M}=1.89, \mathrm{SD}=1.29\right)$.

Radio news. This variable was created by averaging scores of two items tapping radio use for information purposes: "How often do you get news from radio?" and "How often do you use radio for news?" $\left(\mathrm{W}^{1}\right.$ Spearman-Brown $=.84 ; \mathrm{M}=4.42, \mathrm{SD}=2.85 ; \mathrm{W}^{2}$ Spearman-Brown $=.85$; $\mathrm{M}=4.35, \mathrm{SD}=2.83)$.

Print news. Respondents were also asked to rate how often they get print news from "local newspapers" and "national newspapers." A third question asked for respondents' overall frequency of print news use (10-point averaged scale, $\mathrm{W}^{1}$ Cronbach $\mathrm{s} \pm=.70 ; \mathrm{M}=4.51, \mathrm{SD}=$ 2.48; $\mathrm{W}^{2}$ Cronbach $\mathrm{s} \pm=.72 ; \mathrm{M}=4.48, \mathrm{SD}=2.52$ ).

$T V$ news use. Respondents were asked to assess their frequency of use of "TV," "network TV," "local TV," and "cable" for getting news, as well as CNN, Fox News, and MSNBC (7 items averaged scale, $\mathrm{W}^{1}$ Cronbach $\mathrm{s} \pm=.79 ; \mathrm{M}=5.15, \mathrm{SD}=2.05 ; \mathrm{W}^{2}$ Cronbach $\mathrm{s} \pm=.80 ; \mathrm{M}=$ $5.17, \mathrm{SD}=2.02)$

Political knowledge. Consistent with prior literature, we created an index that included measures of respondents' awareness of current policy issues and, more generally, of the U.S. political system and institutional rules (see Delli Carpini \& Keeter, 1993). The first two 
questions were open-ended and asked respondents to name the positions held by Joe Biden and John Roberts at that moment. The other six items were multiple choice and asked respondents to identify the length of a term for U.S. Senators, the budget item on which the U.S. Federal government spent the least, the party affiliation of the Senators who introduced the immigration bill, the outcome of the decision of the Supreme Court about so-called "Obamacare," the name of the organization whose documents were released by Edward Snowden, and the subject matter of the negotiations between the UN, the US, and the Syrian government. We coded correct responses to each item were coded as 1 , and incorrect or missing responses were coded as 0 . Researchers generated indexes of political knowledge identically for Wave 1 and Wave 2 (range $=0$ to 8,8 items additive scales). Mokken scaling and reliability analysis (see Mokken, 1971 for details) showed that the eight items form a unidimensional and reliable scale ( $\mathrm{W}^{1}$ Loevinger's $\mathrm{H}$ scale coefficient $=.47 ; \mathrm{MS} \mathrm{Á}=.77 ; \mathrm{M}=4.58 ; \mathrm{SD}=2.17 ; \mathrm{W}^{2}$ Loevinger's $\mathrm{H}$ scale coefficient $=$ $.42 ; \mathrm{MS} \hat{A}=.81 ; \mathrm{M}=4.23, \mathrm{SD}=2.07)$.

\section{Independent Variable}

News finds me. Our main independent variable comprises personal perceptions about whether individuals can stay informed about current affairs despite not purposely following the news, because important information will "find them" anyway through their general Internet use, peers, and connections within online social networks. This perception was measured using a 10-point Likert-type scale $(1=$ strongly disagree to $10=$ strongly agree $)$, through which respondents expressed either dissent or agreement with the following statements: "I rely on my friends to tell me what's important when news happens," "I can be well informed even when I don't actively follow the news," "I don't worry about keeping up with the news because I know news will find 
me," and "I rely on information from my friends based on what they like or follow through social media" (4 items averaged scale, $\mathrm{W}^{1}$ Cronbach $\left.\mathrm{s} \pm=.73 ; \mathrm{M}=3.58 ; \mathrm{SD}=1.76\right)$.

\section{Control Variables}

In order to account for potential confounds, we included a variety of control variables that have been shown in previous literature to have an impact on our dependent variables, "news use" and "political knowledge," in the analysis. For instance, Kenski and Stroud (2006) found that political knowledge varies according to demographics such as gender, race, education, and income. Thus, we included sociodemographic variables such as respondents' gender $(49.7 \%$ females), age $(\mathrm{M}=52.71, \mathrm{SD}=14.72)$, and race $(77.9 \%$ white $)$. We also controlled for education, operationalized as highest level of formal education completed $(\mathrm{M}=3.61, \mathrm{Mdn}=$ some college); and income, which was measured through eight categories related to the total annual household income $(\mathrm{M}=4.46, M d n=\$ 50,000$ to $\$ 59,999)$. Motivation to learn about politics and prior behaviors should also affect levels of political knowledge; if individuals are driven to learn about politics and engage in politically relevant behaviors, they should become more knowledgeable. Based on Delli Carpini and Keeter's (1996, p. 180-181) model of political knowledge, also controlled for motivational and behavioral political variables that are among the strongest predictors of knowledge and include discussion network size, discussion frequency, internal political efficacy, political interest, and trust in the media. Finally, we accounted for overall social media use frequency $(M=4.13 ; \mathrm{SD}=2.98)$, infotainment $(\mathrm{M}=2.44 ; \mathrm{SD}=2.43)$, and incidental exposure to information, as these variables may be closely related to news-findsme perceptions and need to be eliminated as potential confounds.

Discussion network size. Talking about politics with others is associated with higher levels of political knowledge (Delli Carpini \& Keeter, 1996) and our models account for two aspects of 
political discussion: network size and frequency. Two open-ended questions asked respondents about the number of people they "talked to face-to-face or over the phone about politics or public affairs," and "talked to via the Internet, including e-mail, chat rooms and social networking sites about politics or public affairs" during the past month. We then created an additive index was then created adding both figures, but the resulting variable was highly skewed ( $\mathrm{W}^{1} M=4.36$, $M d n=1.00, S D=16.89$, skewness $=10.86)$. We then used the natural logarithm to reduce the skewness and bring the distribution closer to the normal curve $\left(\mathrm{W}^{1} M=.33, M d n=.24, S D=\right.$ .37 , skewness $=1.32$ )

Discussion frequency. We computed this variable based on questions that asked respondents about the frequency of political talk with people to whom they maintained relations with varying degrees of closeness (Valenzuela et al., 2012; Bachmann \& Gil de Zúñiga, 2013). The questions asked respondents how often they talk about politics or public affairs with: "Spouse or partner," "family and relatives," "friends," “acquaintances," "strangers," "neighbors you know well," "coworkers you know well," and “coworkers you do not know well” (9 items averaged scale, $\mathrm{W}^{1}$ Cronbach $\left.\mathrm{s} \pm=.87 ; \mathrm{M}=3.27 ; \mathrm{SD}=1.74\right)$.

Internal political efficacy. Efficacious individuals who feel they can understand and comprehend political information are more likely to consume news and be knowledgeable (Delli Carpini \& Keeter, 1996; Kenski \& Stroud, 2006). The questionnaire asked respondents the extent of their agreement (from strongly agree to strongly disagree, 10-point scale) with two statements: "I have a good understanding of the important political issues facing our country," and "I consider myself well qualified to participate in politics" $\left(\mathrm{W}^{1}\right.$ Spearman-Brown Coefficient $=.87$; $\mathrm{M}=5.34 \mathrm{SD}=2.56)$ 
Political interest. Individuals who are interested in politics are likely to consume more news and be more knowledgeable politically (e.g. Kenski \& Stroud, 2006). Respondents were asked to rate their degree of interest in 'information about what's going on in politics and public affairs," as well as their level of attention to "information about what's going on in politics and public affairs" $\left(2\right.$ items averaged scale, $\mathrm{W}^{1}$ Spearman-Brown coefficient $=.97 ; \mathrm{M}=6.67 \mathrm{SD}=$ 2.70).

Media trust: Given that those who do not trust the media are less likely to use it and less knowledgeable (Ardèvol-Abreu \& Gil de Zúñiga, 2016; Delli Carpini \& Keeter, 1996), this study employed four questions asking respondents how much they trusted news from "mainstream news media," “alternative news media," "social media sites," and "news aggregators" (10-point averaged scale, $\mathrm{W}^{1}$ Cronbach $\left.\mathrm{s} \pm=.72 ; \mathrm{M}=4.28 ; \mathrm{SD}=1.72\right)$.

Incidental news exposure: Incidental news exposure may be positively related to people's perception that news finds them, making it important that we control for this potential confounding effect. Building on measures previously used in the literature (Tewksbury et al., 2001; Kim et al., 2013) respondents were asked nine items tapping to what extent they encounter or come across news when they were using media for something else. Items included 'television,' 'radio,' 'mobile devices,' 'search engines,' 'blog,' 'online portals,' 'e-mail,' ‘microblogging (i.e., Twitter),' and 'social networking sites' (10-point averaged scale, W' Cronbach $\mathrm{s} \pm=.85 ; \mathrm{M}=3.87 ; \mathrm{SD}=1.75)$.

\section{Statistical Analyses}

To test our set of hypotheses and research questions, a series of regression analyses were conducted. First, two series of lagged, autoregressive (controlling for prior effects of the dependent variable) ordinary least-square regressions were conducted to assess the effect of 
news-finds-me perceptions on the dependent variables. The rational here is that although crosssectional models may help understand how variables are related to each other, as well as time lagged models, both may be biased when addressing causal inference. An autoregressive model helps alleviate this issue (see Maxwell, Cole, \& Mitchell, 2011). Bias in cross-sectional analyses of longitudinal mediation: Partial and complete mediation under an autoregressive model. Finally, we constructed a regression-based, lagged mediation path model to test whether there was an indirect effect of news-finds-me perceptions on political knowledge via social media news use, using the PROCESS macro in SPSS (Hayes, 2013).

\section{Results}

This study first sought to identify news media consumption patterns among those who have the perception that the active search for news is not necessary, as news will reach them one way or another. Thus, our first set of hypotheses examined the effects of news-finds-me perceptions on the use of different news media. We expected news-finds-me perceptions to be positively associated with social media use for informational purposes (H1) and negatively associated with traditional media use $(\mathrm{H} 2)$. To test these hypotheses, we constructed autoregressive lagged regression models predicting different types of media use for news, including television, newspapers, radio, and social media. Consistent with our expectations, the results in Table 1 show that the news-finds-me perception (W1) is negatively associated with traditional news media consumption (W2), specifically television $\left({ }^{2}=-.041, p<.05\right)$ and newspapers $\left({ }^{2}=-.066\right.$, $p<.001)$. That is, the more the people tend to perceive important news will reach them, the less they actively consume information in the future. On the other hand, news-finds-me beliefs showed no significant relationships with radio news use $\left({ }^{2}=.006, p=.238\right)$. 
Also consistent with our expectations, results from the autoregressive hierarchical regression model indicate a positive relationship between the news-finds-me belief and social media use for news $\left({ }^{2}=.062, p<.001\right)$. Among all the controls in the autoregressive model, as it should be expected, previous types of media consumption were the strongest predictors for future engagement with the same type of news media. These results support our expectations that the news-finds-me perception is associated with less use of traditional media, but greater use of social media for informational purposes. Within time, however, the use of social media will more strongly predict the formation of NFM perception $\left(\mathrm{r}_{\text {cross-lagged }}=.43, p<.001\right)$ than the other way around $\left(\mathrm{r}_{\text {cross-lagged }}=.18, p<.001\right)($ See Table 5$)$.

\section{$<$ Insert Table 1 Here $>$}

RQ1 addressed the relationship between the news-finds-me perception and political knowledge. We began with a cross-sectional test on the effect of news-finds-me perception in predicting people's knowledge levels. Furthermore, we also employed lagged and autoregressive models to shed light on the effects of news-find-me perception on political knowledge over time (see Hsiao, 2014; Shah, Cho, Eveland, \& Kwak, 2005). As presented in Table 2, results suggest that the news-finds-me perception is overall negatively associated to political knowledge. These effects are consistent in the cross-sectional analysis $\left({ }^{2}=-.108, p<.001\right.$; " $\left.\mathrm{R} 2=0.8 \%\right)$, lagged model $\left({ }^{2}=-.111, p<.001 ; " \mathrm{R} 2=0.9 \%\right)$, and the autoregressive test $\left({ }^{2}=-.047, p<.05 ; " \mathrm{R} 2=\right.$ $0.3 \%$ ). This finding indicates that individuals who perceive that news will find them also tend to show lower levels of political knowledge, even after controlling for sociodemographics, personal antecedents, news media use, and even political knowledge over time.

Among all the controls introduced in the different models, age, gender (male), education, income, discussion network size, discussion frequency, internal efficacy, and political interest 
positively predicted political knowledge. Infotainment, TV news, and social media use also predicted political knowledge, although differently (see Table 2 for details) ${ }^{1}$. The study also includes a correlation table of all variables of interest in the study (see Table 3).

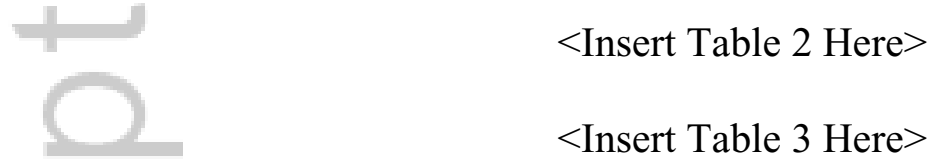

To further explore the relationships between the news-finds-me perception and political knowledge - and because we expected (and empirically found) our independent variable to be positively related to social media use for news - possible indirect effects were examined (RQ2). For this purpose, we carried out three mediation models testing indirect effects of news-finds-me beliefs on political knowledge through social media use for news (see Hayes, 2013 for details). As Table 4 shows, we found no significant indirect effect on political knowledge in crosssectional or lagged: [-.0314, .0013], and [-.0227, .0085], respectively. Those who expect that the news will find them tend to be exposed to more news and political information on social media. However, this path does not represent an indirect net gain effect on their level of political knowledge.

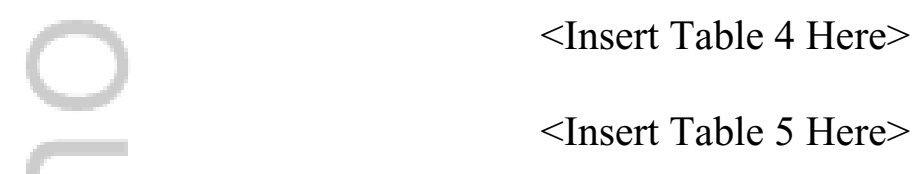

Overall, these results suggest that news-finds-me perceptions reduce surveillance about public affairs via traditional media (TV and newspapers), and are associated with a decrease in political knowledge. Given that the news-finds-me perception is associated with increased use of social media for informational purposes, one might think that those scoring high in "news finds

\footnotetext{
I The incremental variance explained by the NFM perception block is statistically significant for all models: TV news - Delta-R ${ }^{2} F(3,911) ; p=0.048$. Print news - Delta- $^{2} F(9,373) ; p=0.002$. Social Media news $-D^{-D e l t a-R^{2}}$ $\mathrm{F}(6,127) ; \mathrm{p}=0.013$. Political Knowledge (cross-sectional) - Delta-R $\mathrm{F}(15,695) ; \mathrm{p}=0.000080$. Political Knowledge (lagged) - Delta-R ${ }^{2} \mathrm{~F}(16,123) ; \mathrm{p}=0.000064$. Political Knowledge (autoregressive) - Delta-R $\mathrm{F}(4,399) ; \mathrm{p}=0.036$
} 
me" could indirectly learn about politics. However, after testing the mediation path we did not find any significant indirect association between news-finds-me perceptions and political knowledge.

\section{Discussion}

The internet and social media provide citizens ample opportunities to be exposed to news and political information, incidentally and through content shared by others in their social networks (Bode, 2016; Kim et al., 2013; Pew, 2016; Garrett et al., 2012). Although the availability of such information may benefit democracy in many ways, the abundance of news online may also contribute to citizens' misperceptions that they can become adequately informed about politics without much explicit effort. This study introduces and finds support for a new media phenomenon that has emerged in the contemporary news environment: the news-finds-me perception and effect. Our results indicate that many individuals hold the mistaken perception that they can be part of a well-informed citizenry, as important news will find them without their actively seeking it. We find that individuals who believe the news finds them are less likely to use traditional sources of news such as television news and newspapers. Also of importance, citizens who hold this perception are less knowledgeable about civic and political affairs than are those who do not believe the news will find them.

The results presented here have important implications for our theoretical understanding of how people learn about politics in an era of digital and social media (also see Gil de Zúñiga, 2015). This study suggests that actively seeking the news continues to be critical for citizens to learn about politics. Although the abundance of information available today creates opportunities for citizens to learn about politics, individual characteristics appear to be important determinants in whether people learn from news. Having a strong interest in staying informed about news and 
political information can increase attention and elaboration on news content, which subsequently facilitates gains in knowledge (e.g. David, 2009; Eveland et al., 2003). The news-finds-me perception represents a psychological detachment from this active news-seeking behavior, which hinders any potential benefits in terms of political knowledge. Prior (2007) has documented citizens' move away from news in favor of entertainment content and the effects this has on political knowledge. Our results are consistent with this work in that the news-finds-me perception contributes to gaps in civic and political learning, as those who hold the perception are less likely to seek traditional forms of news and are less knowledgeable about politics. Based on our results we suggest the news-finds-me perception is likely to widen gaps in political knowledge, rather than vice versa. It seems unlikely that those who lack political knowledge in the first place come to increasingly believe the news will find them. That is, if they are not knowledgeable about politics to begin with, it is unlikely that they think about the news and how it reaches them. On the other hand, if they believe the news will find them but do not actively engage with it, their levels of knowledge also stall. Perhaps most problematic, those who hold the news-finds-me perception actually believe they are staying informed when in reality this misperception is detrimental to their levels of knowledge.

The findings are even more troubling when considering that those who hold the perception that news will find them were more likely to use social media for informational purposes, but exposure to news in this context did not facilitate political learning. In short, the reliance of social media use to passively overcome their information consumption gap, and to learn about important news, does not increase knowledge about politics. Prior research indicates that a saturated news environment can close the knowledge gap between individuals motivated to consume news and those who are not, as citizens are more likely to glean political knowledge if 
relevant information is widely available (e.g. Elenbaas et al., 2014; Iyengar et al., 2010; Shehata, 2013). Yet the results of the present study suggest that the benefits of such a saturated media environment may not always extend to social media. That is, people may be frequently exposed to news and political information in social media, but this does not translate into gains in political knowledge for those individuals who have the perception that important news will eventually get pushed their way. We do not suggest that social media inhibits learning or that social media users are less knowledgeable than traditional media users. Rather, we argue that social media may be changing how some people think about the role of news in their lives and their intentions to seek it out, which may affect what they know about politics. This finding hints at the interesting possibility that social media are useful in promoting some aspects of democracy but not others. In particular, social media may in part be contributing to a more participatory but less knowledgeable public. We know, for example, that social media encourage political expression and participation, and lower the barriers to become involved in politics (e.g. Bennett, 2012; Gil de Zúñiga, Molyneux, \& Zheng, 2014). But whether social media facilitate political learning remains an open question, as preliminary evidence suggests use of these outlets are not strongly contributing to political knowledge (e.g. Bode, 2016; Dimitrova et al., 2014). Citizens likely see social media more as a form of entertainment than a source of news (Pew, 2014). As a result, they may lack the necessary desire to truly learn from such news exposure (Prior, 2007). It is also possible that the type of news content in social media does not provide people with the necessary information they need to learn about politics (Bright, 2016). This was not possible to ascertain with our data as we did not have specific news content associated to people's social media news use but continue to be an important avenue for future exploration. 
It must also be noted that although we do find news-finds-me effects, depending on the model these perceptions account for between .3 to $.9 \%$ of the variance in political knowledge. These effect sizes must be taken into account when interpreting the results. While the overall strength of these effects are modest, news-finds-me perceptions uniquely explain changes in contemporary media consumption patterns and overall political knowledge, suggesting that it aids our theoretical understanding of how people learn from the news in today's media environment.

This study has to be interpreted in the light of some limitations on the generalizability of the results. Our participants were recruited from an online opt-in panel, which implies a nonprobability convenience sample. Thus, although the demographic breakdown in both waves is comparable to the U.S. Census (see Saldaña et al., 2015; Weeks et al., 2015), our sample may not be fully representative of all the characteristics of the U.S. population. Despite this limitation, the quality of our sample at selection (using quotas for key demographic variables), the relatively large sample size, the diversity of the respondents, and the number of control variables used in all models allow us to be reasonably confident about the validity and generalizability of our findings (for a more detailed discussion about the validity of opt-in panels to explain theoretical relationships between variables, see Baker et al., 2013).

The internet and social media can encourage democratic outcomes but can also provide people a false sense of being informed. In particular, the abundance of news online and in social media can breed the notion that people no longer need to actively seek news. If one's friends and social networks share all the relevant news anyway, why should people seek it out on their own? This study indicates that people need to seek news because it will not find them, and if they hold such a belief, their knowledge of public affairs will suffer. 


\section{References}

American Association of Public Opinion Research (AAPOR) (2011). Standard definitions: final dispositions of case codes and outcome rates for surveys.

Ardèvol-Abreu, A., \& Gil de Zúñiga, H. (2016). Effects of editorial media bias perception and media trust on the use of traditional, citizen, and social media news. Journalism \& Mass

Communication Quarterly. Advance online publication. doi: 10.1177/1077699016654684

Bachmann, I., \& Gil de Zúñiga, H. (2013). News platform preference as a predictor of political and civic participation. Convergence: The International Journal of Research into New Media Technologies. 19(4) 496-512. doi: 10.1177/1354856513493699

Barabas, J., \& Jerit, J. (2009). Estimating the causal effects of media coverage on policy-specific knowledge. American Journal of Political Science, 53, 73-89. doi: 10.1111/j.15405907.2008.0035.x

Bennett, W. L. (2012). The personalization of politics: Political identity, social media, and changing patterns of participation. The ANNALS of the American Academy of Political and Social Science, 644, 20-39. doi: 10.1177/0002716212451428

Bode, L., (2016). Political news in the news feed: Learning politics from social media. Mass Communication \& Society, 19, 24-48. doi: 10.1080/15205436.1045149

Bode, L., Vraga, E. K., Borah, P., \& Shah, D. V. (2014). A new space for political behavior: political social networking and its democratic consequences. Journal of Computer Mediated Communication, 19, 414-429. doi: 10.1111/jcc4.12048

Bosnjak, M., Das, M., \& Lynn, P. (2016). Symposium issue on methods for probability-based online and mixed-mode panels. Social Science Computer Review, 34, 3-7. doi: $10.1177 / 0894439315579246$.

This article is protected by copyright. All rights reserved. 
Bright, J. (2016). The social news gap: how news reading and news sharing diverge. Journal of Communication, 66, 343-365. doi: 10.1111/jcom.12232.

David, C. C. (2009). Learning political information from the news: A closer look at the role of motivation. Journal of Communication, 59, 243-261. doi: 10.1111/j.1460-

2466.2009.01414.x

Delli Carpini, M. X., \& Keeter, S. (1996). What Americans know about politics and why it matters. New Haven, CT: Yale University Press.

Dimitrova, D.V., Shehata, A., Strömbäck, J., \& Nord, L.W. (2014). The effects of digital media on political knowledge and participation in election campaigns: Evidence from panel data. Communication Research, 41, 95-118. doi: 10.1177/0093650211426004

Elenbaas, M., de Vreese, C., Schuck, A., \& Boomgaarden, H. (2014). Reconciling passive and motivated learning: The saturation-conditional impact of media coverage and motivation on political information. Communication Research, 41, 481-504. doi:

$10.1177 / 0093650212467032$

Eveland, W. P., Shah, D. V., \& Kwak, N. (2003). Assessing causality in the cognitive mediation model: A panel study of motivations, information processing, and learning during campaign 2000. Communication Research, 30, 359-386. doi:

$10.1177 / 0093650203253369$

Garret, K., Bimber, B., Gil de Zúñiga, H., Heinderyckx, F., Kelly, J. \& Smith, M. (2012). New ICTs and the study of political communication. International Journal of Communication $6,214-231$.

This article is protected by copyright. All rights reserved. 
Gil de Zúñiga, H., (2015). Toward a European public sphere? The promise and perils of modern democracy in the age of digital and social media. International Journal of Communication, 9:3152-3160.

Gil de Zúñiga, H., Molyneux, L., \& Zheng, P. (2014). Social media, political expression, and political participation: Panel analysis of lagged and concurrent relationships. Journal of Communication 64, 612-634. doi: 10.1111/jcom.12103

Gil de Zúñiga, H., \& Hinsley, A. (2013). The press versus the public: What is "good journalism? Journalism Studies 14(6) 926-942. doi:10.1080/1461670X.2012.

Hargreaves, I., \& Thomas, J. (2002). New news, old news. London: Independent Television Commission/Broadcasting Standards Commission.

Hayes A. F. (2013). Introduction to mediation, moderation, and conditional processes: a regression-based approach. New York, London: Guilford Press.

Hermida, A. (2010). From TV to Twitter: How ambient news became ambient journalism. Media-culture Journal, 13. Retrieved from http://www.journal.mediaculture.org.au/index.php/mcjournal/article/view/220

Hopmann, D.N., Wonneberger, A., Shehata, A., \& Höijer, J. (2016). Selective media exposure and increasing knowledge gaps in Swiss referendum campaigns. International Journal of Public Opinion Research, 28, 73-95. doi: 10.1093/ijpor.edv002.

Hsiao, C. (2014). Analysis of panel data. Cambridge University Press.

Iyengar, S., Curran, J., Lund, A.B., Salovaara-Moring, I., Hahn, K. S., \& Coen, S. (2010). Crossnational versus individual-level differences in political information: A media systems perspective. Journal of Elections, Public Opinion and Parties, 20, 291-309. doi:

$10.1080 / 17457289.2010 .490707$

This article is protected by copyright. All rights reserved. 
Iyengar, S., \& Hahn, K. S. (2009). Red Media, Blue Media: evidence of ideological selectivity in media use. Journal of Communication, 59, 19-39. doi: 10.1111/j.14602466.2008.01402.x.

Katz, E., \& Lazarsfeld, P. (1955). Personal influence. New York: The Free Press.

Kenski, K., \& Stroud, N. J. (2006). Connections between internet use and political efficacy, knowledge, and participation. Journal of Broadcasting \& Electronic Media, 50, 173-192. doi: 10.1207/s15506878jobem5002_1

Kim, Y., Chen, H., \& Gil de Zúñiga, H. (2013). Stumbling upon news on the internet: Effect of incidental news exposure and relative entertainment use on political participation. Computers in Human Behavior, 29, 2607-2614. doi: 10.1016/j.chb.2013.06.005

Knobloch-Westerwick, S., Carpentier, F.D., Blumhoff, A., \& Nickel, N. (2005). 3Journalism \& Mass Communication Quarterly, 82, 181-195. doi: 10.1177/107769900508200112

Kobayashi, T., \& Inamasu, K. (2015). The knowledge leveling effect of portal sites.

Communication Research, 42, 482-502. doi: 10.1177/0093650214534965

Krugman, H.E., \& Hartley, E.L. (1970). Passive learning from television. Public Opinion Quarterly, 34, 184-190. doi: 10.1086/267788.

Locascio, J.J (1982). The cross-lagged correlation technique: Reconsideration in terms of exploratory utility, assumption specification and robustness. Educational and Psychological Measurement, 42(4), 1023-1036.

Maxwell, S. E., Cole, D. A., \& Mitchell, M. A. (2011). Bias in cross-sectional analyses of longitudinal mediation: Partial and complete mediation under an autoregressive model. Multivariate Behavioral Research, 46(5), 816-841.

This article is protected by copyright. All rights reserved. 
Min, S.J. (2010). From the digital divide to the democratic divide: Internet skills, political interest, and the second-level digital divide in political internet use. Journal of Information Technology \& Politics, 7, 22-35. doi: 10.1080/19331680903109402

Mokken, R. J. (1971). A theory and procedure of scale analysis. De Gruyter: Berlin.

Park, C.S. (2013). Does Twitter motivate involvement in politics? Tweeting, opinion leadership, and political engagement. Computers in Human Behavior, 29, 1641-1648. doi: 10.1016/j.chb.2013.01.044

Pentina, I., \& Tarafdar, M. (2014). From “information” to "knowing": Exploring the role of social media in contemporary news consumption. Computers in Human Behavior, 35, 211-223. doi: 10.1016/j.chb.2014.02.045

Pew Research Center (2016, 7 July). The modern news consumer: News attitudes and practices in the digital era. Retrieved from http://www.journalism.org/2016/07/07/the-modernnews-consumer/

Pew Research Center (2014, 26 March). 8 key takeaway about social media and news. Retrieved from http://www.journalism.org/2014/03/26/8-key-takeaways-about-social-media-andnews/

Prior, M. (2007). Post-broadcast democracy: How media choice increases inequality in political involvement and polarizes elections. Cambridge, UK: Cambridge University Press.

Saldaña, M., McGregor, S., and Gil de Zúñiga, H., (2015). Social media as a public space for politics: Cross-national comparison of news consumption and participatory behaviors in the United States and the United Kingdom. International Journal of Communication, 9:3304-3326.

This article is protected by copyright. All rights reserved. 
Shah, D. V., Cho, J., Eveland, Jr., W.P., \& Kwak, N. (2005). Information expression in a digital age: Modeling internet effects on civic participation. Communication Research, 32, 531565. doi: $10.1177 / 0093650205279209$.

Shehata, A. (2013). Active or passive learning from television? Political information opportunities and knowledge gaps during election campaigns. Journal of Elections, Public Opinion, and Parties, 23, 200-222. doi: 10.1080/17457289.2013.771362.

Shehata, A., Hopmann, D.M., Nord, L., \& Höijer, J., (2015). Television channel content profiles and differential knowledge growth: A test of the inadvertent learning hypothesis using panel data. Political Communication, 32, 377-395. doi: 10.1080/10584609.2014.955223

Strömbäck, J., Djerf-Pierre, M., \& Shehata, A. (2013). The dynamics of political interest and news media consumption: A longitudinal perspective. International Journal of Public Opinion Research, 25, 414-435. doi: 10.1093/ijpor/eds018

Tewksbury, D., Weaver, A. J., \& Maddex, B. D. (2001). Accidentally informed: Incidental news exposure on the world wide web. Journalism \& Mass Communication Quarterly, 78, 533-554. doi: 10.1177/107769900107800309

Trilling, D., \& Schoenbach, K. (2013). Skipping current affairs: The non-users of online and offline news. European Journal of Communication, 28, 35-51. doi: $10.1177 / 0267323112453671$

Valenzuela, S., Kim, Y., \& Gil de Zúñiga, H. (2012). Social networks that matter: Exploring the role of political discussion for online political participation. International Journal of Public Opinion Research 24(2), 163-184. doi: 10.1093/ijpor/edr037

Watson, N., \& Wooden, M. (2006). Modeling longitudinal survey response: The experience of the HILDA survey. Paper presented at the ACSPRI Social Science Methodology 
Conference, Sydney, Australia. Retrieved

from http://old.acspri.org.au/conference2006/proceedings

Wei, L., \& Hindman, D.B. (2011). Does the digital divide matter more? Comparing the effects of new media and old media use on the education-based knowledge gap. Mass

Communication \& Society, 14, 216-235. doi: 10.1080/15205431003642707

Weeks, B.E., Ardévol-Abreu, A., \& Gil de Zúñiga, H. (2015). Online influence? Social media use, opinion leadership, and political persuasion. International Journal of Public Opinion Research. Advance online publication. doi: 10.1093/ijpor/edv050

Weeks, B.E., \& Holbert, R. L. (2013). Predicting dissemination of news content in social media: A focus on reception, friending, and partisanship. Journalism \& Mass Communication Quarterly, 90, 212-232. doi: 10.1177/1077699013482906

Yoo, S. W., \& Gil de Zúñiga, H. (2014). Connecting blog, Facebook, and Twitter use with gaps in knowledge and participation. Communication \& Society. 27(4) 33-48. doi:

$10.15581 / 003.27 .4 .33-48$

Zukin, C., \& Snyder, R. (1984). Passive learning: When the media environment is the message.

Public Opinion Quarterly, 48, 629-639. doi: 10.1086/268864

Table 1. Panel Autoregressive Models Testing News-Finds-Me Effect on News Use

\begin{tabular}{lclcc}
\cline { 2 - 5 } & $\begin{array}{c}\mathbf{T V} \\
\text { News }\end{array}$ & $\begin{array}{c}\text { Print } \\
\text { News }\end{array}$ & $\begin{array}{c}\text { Radio } \\
\text { News w2 }\end{array}$ & $\begin{array}{c}\text { Social } \\
\text { Media } \\
\text { News }\end{array}$ \\
\hline Block 1: & & & & \\
Demographics & .029 & $.045^{*}$ & .016 & $-.057 * * *$ \\
Age & .014 & .013 & -.023 & -.018 \\
Gender (female) & -.004 & .013 & .007 & -.022 \\
Education & -.002 & .017 & .018 & -.024 \\
Income & $-.036^{*}$ & -.013 & $-.032 \#$ & $-.059 * *$ \\
Race (white) & $8.6 \%$ & $9.3 \%$ & $4.2 \%$ & $9.8 \%$ \\
\multicolumn{1}{c}{${ }^{2}$} & & & &
\end{tabular}

This article is protected by copyright. All rights reserved. 
Block 2: Antecedents

\begin{tabular}{|c|c|c|c|c|}
\hline Dis. Net. Size ${ }^{\mathrm{Wl}}$ & -.017 & -.009 & -.036 & $.052 *$ \\
\hline Dis. Frequency ${ }^{\mathrm{W} 1}$ & $.043 \#$ & .026 & .035 & -.004 \\
\hline Int. Efficacy ${ }^{\mathrm{w} 1}$ & -.001 & -.017 & .026 & -.006 \\
\hline Political Interest ${ }^{\mathrm{Wl}}$ & .028 & .035 & $.053 \#$ & .026 \\
\hline Media Trust ${ }^{\mathrm{W} 1}$ & $.040 \#$ & .036 & $-.052 *$ & $.052 \#$ \\
\hline Social Media Freq. ${ }^{\text {wl }}$ & -.001 & -.015 & .020 & $.092 * * *$ \\
\hline $\mathrm{R}^{2}(\%)$ & $18 \%$ & $12 \%$ & $8.1 \%$ & $26 \%$ \\
\hline
\end{tabular}

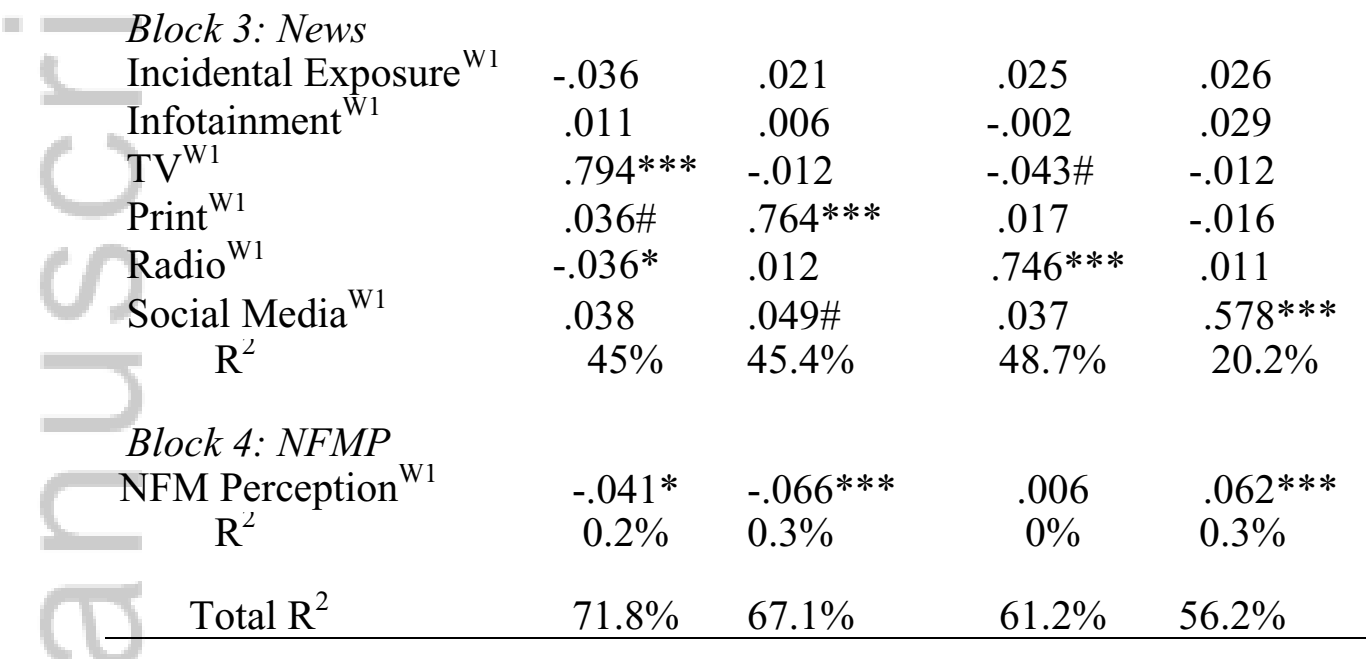

Note: Sample size $=1,017$. Cell entries are final-entry OLS standardized Beta $\left({ }^{2}\right)$ coefficients. $\# p$ $<.1 ; * p<.05 ; * * p<.01 ; * * * p<.001$.

Table 2. Cross-sectional, Lagged, and Autoregressive Regression Models Testing News Finds Perception Over Political Knowledge

\begin{tabular}{|c|c|c|c|}
\hline & $\begin{array}{l}\text { Political } \\
\text { Knowledge w1 } \\
\text { (Cross-sectional) }\end{array}$ & $\begin{array}{l}\text { Political } \\
\text { Knowledge } \\
\text { (Lagged) }^{\text {(Lagged }}\end{array}$ & 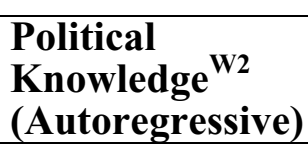 \\
\hline \multicolumn{4}{|l|}{ Block 1: } \\
\hline Age & $.052 \#$ & .024 & -.007 \\
\hline Gender (female) & $-.174 * * *$ & $-.182 * * *$ & $-.078 * * *$ \\
\hline Education & $.099 * * *$ & $.110 * * *$ & $.051 * *$ \\
\hline Income & $.100 * * *$ & $.088 * * *$ & .028 \\
\hline
\end{tabular}

This article is protected by copyright. All rights reserved. 


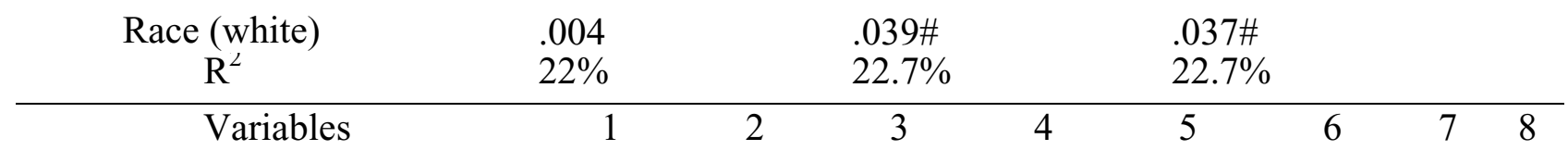

\section{Block 2: Antecedents}

Dis. Net. Size ${ }^{\mathrm{W} 1}$

Dis. Frequency ${ }^{\mathrm{W}} \mathrm{I}$

Int. Efficacy ${ }^{\text {w }}$

Political Interest ${ }^{\mathrm{W}}$

Media Trust ${ }^{\mathrm{W}} \mathrm{I}$

Social Media Freq. ${ }^{\text {W1 }}$

$\mathrm{R}^{2}(\%)$

$\begin{array}{lll}.104 * * * & .086 * * & .020 \\ -.069 * & -.050 & .002 \\ .082 * * & .104 * * * & .054 * \\ .433 * * * & .395 * * * & .135 * * * \\ .011 & -.018 & -.024 \\ -.016 & -.029 & -.020 \\ 21.9 \% & 20.2 \% & 20 \%\end{array}$

Block 3: News

Incidental Exposure ${ }^{\mathrm{W} 1}$

Infotainment $^{\mathrm{W} 1}$

TV ${ }^{\mathrm{Wl}}$

Print $^{\mathrm{Wl}}$

Radio $^{\mathrm{W}}$

Social Media ${ }^{\mathrm{W}}$ $\mathrm{R}^{2}$

.013

$.125 * * *$

.013

.004

$-.137 * * *$

$.109 * * *$

.004

$-.033$

$-.108 * * *$

$-.027$

.014

$-.020$

$-.001$

$-.006$

$-.015$

$-.034$

$-.076^{*}$

$-.057 \#$

$2.4 \%$

$2.0 \%$

$2.1 \%$

Block 4: Autoregressiv

Pol. Knowledge ${ }^{W}$

$$
\mathrm{R}^{2}
$$

$$
---
$$

$--$

$.597 * * *$

$19.6 \%$

\section{Block 4: NFMP}

NFM Perception $^{\mathrm{Wl}}$

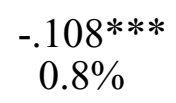

$-.111 * * *$
$0.9 \%$

$-.047^{*}$

$\mathrm{R}^{2}$

$47.1 \%$

$45.7 \%$

$64.5 \%$

Note: Sample size $=1,017$. Cell entries are final-entry OLS standardized Beta $\left({ }^{2}\right)$ coefficients. \#p $<.10 ; * p<.05 ; * * p<.01 ; * * * p<.001$

Table 3. Zero-order correlations among all key variables in the study

This article is protected by copyright. All rights reserved. 
1. News finds me $\left(\mathrm{W}^{1}\right)$

2. Social media use for news (

$\left.\mathrm{W}^{2}\right)$

3. Citizen journalism use $\left(\mathrm{W}^{2}\right)$

4. News aggregators use $\left(\mathrm{W}^{2}\right)$

5. Radio news $\left(\mathrm{W}^{2}\right)$

6. Print news $\left(\mathrm{W}^{2}\right)$

7. TV news use $\left(\mathrm{W}^{2}\right)$

8. Political knowledge $\left(\mathrm{W}^{2}\right)$ $-$ $.39 * * \quad-$ $.22 * * \quad .53 * * * \quad--$ $.17 * * \quad .48 * * * \quad .45 * * * \quad--$ $\begin{array}{lllll}.06 & .18 * * * & .27 * * * & .20 * * * & -\end{array}$ $\begin{array}{llllll}.05 & .17 * * * & .30 * * * & .15 * * * & .35 * * * & -\end{array}$ $\begin{array}{llllll}-.04 & .22 * * * & .31 * * * & .16 * * * & .20 * * * & .42 * * *\end{array}$

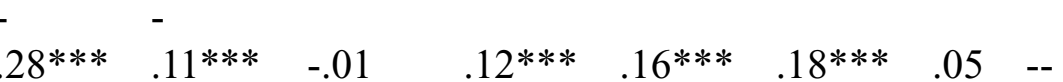

Note. Sample size $=1,008$. Cell entries are two-tailed zero-order correlation coefficients. $\# p<$ $.10 ; * p<.05 ; * * p<.01 ; * * * p<.001$

Table 4. Indirect Effects Test of News Find Me Beliefs over Political Knowledge via Social Media News Use

Indirect Effects Paths

Point 95\% Conf. Estima Interval

e

News Find Me $\left(\mathrm{W}^{1}\right) \rightarrow$ Social Media News Use $\left(\mathrm{W}^{1}\right) \rightarrow$ Political Knowledge $\left(\mathrm{W}^{1}\right)$ $-\quad-.0314$ to $.0109 \quad .0013$

News Find $\mathrm{Me}\left(\mathrm{W}^{1}\right) \rightarrow$ Social Media News Use $\left(\mathrm{W}^{1}\right) \rightarrow$ Political Knowledge $\left(\mathrm{W}^{2}\right)$ $-\quad-.0227$ to $.0051 \quad .0085$

Note: Path estimates are unstandardized coefficients. Indirect effects based on bootstrapping to 5,000 samples with biased corrected confidence intervals. The effects of demographic variables (age, gender, education, race, and income), sociopolitical antecedents (political efficacy, political interest, discussion network size, frequency of discussion, political knowledge, social media use frequency), and media related variables and uses (media trust, incidental exposure to news, infotainment, TV news, Radio news, Print news) were included as control variables. Sample- $W^{1}=1,814$; Sample- $W^{2}=1,017$.

Table 5. Cross-lagged Pearson's Correlation of News Find Me Perception and Social Media News Use

\section{Pearson Coefficient Effects} $\mathbf{r}_{\text {cross-lagged }}$ p-value

News Find Me Perception $\left(\mathrm{W}^{1}\right) \rightarrow$ Social Media News Use $\left(\mathrm{W}^{2}\right)$ .18 .001

Social Media News Use $\left(\mathrm{W}^{1}\right) \rightarrow$ News Find Me Perception $\left(\mathrm{W}^{2}\right)$ 
Note. The cross-lagged correlation has been calculated using Locascio's formula (1982).

\section{Acknowledgments}

The first author would like to thank everyone who helped him in shaping and developing the News-finds-me perception theory since 2009. That includes his former colleagues at the CJCR and DMRP at University of Texas - Austin, as well as members of the MiLab at University of Vienna. Special thanks are due to Seth Lewis, Sebastián Valenzuela, Nakown Jung, Yonghwan Kim and Teresa Correa.

\section{About the Authors}

Homero Gil de Zúñiga holds the Medienwandel Professorship at University of Vienna, Austria, where he leads the Media Innovation Lab (MiLab). He is also a Research Fellow at the Universidad Diego Portales, and a Research Collaborator at Princeton University. His research addresses the influence of new technologies and digital media over people's daily lives, as well as the effect of such use on the overall democratic process. Address: Media Innovation Lab, Department of Communication, University of Vienna, Währinger Straße 29, 1090 Vienna, Austria.

Brian Weeks is an Assistant Professor in the Department of Communication Studies and a Faculty Associate in the Center for Political Studies at the University of Michigan. His research interests include political misinformation and misperceptions, news on social media, and political information sharing online. Address: Department of Communication Studies and Center for Political Studies, University of Michigan, 5432 North Quad, 105 S State St, Ann Arbor, MI 48109 USA

Alberto Ardèvol-Abreu is an Assistant Professor at the Universidad de La Laguna (Spain), where he is also part of the 'Laboratorio de Tecnologías de la Información y Nuevos Análisis de Comunicación Social' (LATINA) research group. His major research interests focus on political communication, political participation, and new media. He is also interested in media representation of immigration and ethnic minorities and its effects on public opinion. Address: Universidad de La Laguna, Departamento de Comunicación y Trabajo Social, Av. César Manrique s/n (Campus de Guadalajara), S/C de Tenerife 38071, Spain. 